\title{
The Implementation of Right-Fulfillment to the Health Care in Achieving the Millennium Development Goal (MDG'S)
}

\author{
Muhammad Zuhri \\ Faculty of Law, Syiah Kuala University \\ Jl. Putroe Phang No.1, Kopelma Darussalam, Banda Aceh, Indonesia. \\ Tel./Fax: +62-651-7554229 E-mail:zuhri_mhd@yahoo.com \\ Basri \\ Faculty of Law, Syiah Kuala University \\ Jl. Putroe Phang No.1, Kopelma Darussalam, Banda Aceh, Indonesia. \\ Tel./Fax:+62-651-7554229 E-mail: basri.fhhumas@gmail.com \\ Submitted: Dec 10, 2015; Reviewed: Jan 22, 2016; Accepted: Feb 13, 2016
}

\begin{abstract}
The vision of Aceh Government in 2012-2017 is Aceh are dignified, prosperous, just, and independent based on the legislation of Aceh government as a form of Memorandum of Understanding. One of the visions of Aceh government 20122017 is the improved welfare of Acehnese people through quality health services through increasing life expectancy, infant mortality, decreasing the prevalence of malnutrition as well as the effectiveness of the treatment of infectious diseases to the achievement of the $M D G$ 's. Model policies adopted by the Aceh government is monitoring and track record of cases, tv monitor, routine and case sms, a special program policy model, and the model of budget balancing. Model policies adopted by the district/city government is making a supporting program, All Village Midwives Must Live in the Village, deliveries assistance is performed by professional health workers, adjustment to the ability of APBK. Support new regulation of Regent Regulation (Perbub) on Malaria Elimination and No Smoking Area. MDG's target is not entirely in accordance with the indicator being built, because it requires adjustments in accordance with the ability of both district or city areas. Regulatory support is not adequate to support the achievement of the MDG's in the field of health.
\end{abstract}

Keywords: Human Rights; Local Government; Millennium Development Goals

DOI: http://dx.doi.org/10.20956/halrev.v1n1.215

\section{INTRODUCTION}

Health is a human right and one of the elements of well-being that must be realized in accordance with the ideals of the Indonesian nation as referred to in Pancasila and the Preamble to the Constitution of the Republic of Indonesia 1945. Therefore, all activities and efforts to improve the public health as high as implemented by the principle of nondiscriminatory, participatory, protection, and sustainable are very important for the formation of human resources in Indonesia, increased sustainability and competitiveness of the nation, as well as national development. 
At first, efforts to improve the highest health is effort to cure the disease, then gradually evolving towards the integration of health activities for the entire community to engage the wider community that include promotive, preventive, curative, and rehabilitative were integrated and sustainable. Planning and financing the build of health is not only focused on treatment (curative), because it would require a bigger budget compared with prevention efforts. Consequently, people will always look at the issue of health financing as something that is consumptive/ wastage. In addition, the viewpoint of policy makers also still regard health as a major need and a worthwhile investment in carrying out development so that health budget is still relatively low when compared with other countries.

For that, it is time we look at health issues as a major factor and a valuable investment that its implementation is based on a new paradigm that is commonly known as the health paradigm, the paradigm that prioritizes health promotion and prevention efforts without neglecting curative and rehabilitative.

Article 224 Act of Aceh Government governs the guarantee of the right to health care, namely:

(1) All Acehnese peoples have equal rights in obtaining health care in order to achieve optimal health status.

(2) All Acehnese peoples are obliged to participate in maintaining and improving the health of individuals, families, and the environment.

(3) Improved health status as referred to in paragraph (2) shall be implemented at least in accordance with the minimum service standards.

(4) All the orphans and the poor had a right to receive comprehensive health services at no cost.

In Article 225 is also arranged in relation to the liability of Aceh government and district/city governments in providing health services, namely:

(1) The Government of Aceh and District/ City Government shall provide health services based on minimum service standards in accordance with the legislation, this does not contradict to the Islamic law.

(2) The Government of Aceh and district/ city government can involve social institutions to play a role in the health field.

In realizing the vision of Aceh is pursued through 5 (five) development mission in Aceh, one of which is what is formulated in the third mission, that is:

Strengthen the economic structure and the quality of human resources is to develop a framework of democratic economy through an increase in the potential of the regions sector in an effort to build an optimal quality of life; reduce poverty and unemployment in meeting the achievement of the Millennium Development Goals (MDG's).

Improving the quality of health of the Acehnese people are realizing quality health services through increasing life expectancy, decline infant mortality, decline prevalence of malnutrition as well as the effectiveness of the treatment of infectious diseases to the achievement of MDG's. The MDG's target in 2015 is as follows: 
1. The increase in life expectancy, which is 72 years old.

2. The decline in the infant mortality per thousand live births, which is 24 per thousand live births.

3. The decline in the maternal mortality per hundred thousand live births, which is 102 per one hundred thousand live births.

4. The decline in the prevalence of malnutrition among children under five $(15 \%)$.

5. The decline in the prevalence of HIV and AIDS is less than $0.5 \%$.

6. The decline in malaria morbidity rate (per 1000 population is less than one per 1000 population.)

7. Increased detection rate of $\mathrm{TB}, \mathrm{BTA}$ new positive. Its target $\geq 70 \%$.

For comparison, the health condition of the Acehnese people based on data from the Health Office in Aceh in 2013 are as follows:

1. Life expectancy, which is 68.9 years.

2. The infant mortality rate of 14.8 per thousand live births.

3. The maternal mortality per hundred thousand live births, which is 183 percent thousand live births.

4. The prevalence of malnutrition in children under five (14.4\%).

5. The prevalence of HIV and AIDS is less than $0.3 \%$.

6. Malaria morbidity is 0.43 .

7. The detection rate of TB, BTA new positive. $\geq 54.3 \%$.

From the data above shows that not all of the MDG's targets can be realized in Aceh, data in Aceh Health Office show that health problems in Aceh is still very complex. Maternal deaths, stillbirths and malnutrition are still high enough above the national average. Data in 2013 showed maternal mortality reaches 151 peoples, infant mortality and malnutrition 1.240 infants and malnutrition 820. Up to 16 April 2014 maternal mortality 36, infant mortality 357 , as well as malnutrition 79 . National life expectancy in 2013 was 72 years, while life expectancy at 68.9 years of Acehnese peoples. Thus, the life expectancy of the Acehnese people is under the national average.

Although, the government of Aceh has implemented policies in such programs as Jaminan Kesehatan Aceh (JKA), and now changed its name to Jaminan Kesehatan Rakyat Aceh (JKRA), but the focus of the program is more dominant in the curative (treatment), whereas health efforts must be implemented integrated and sustainable for all health efforts that is promotive, preventive, curative and rehabilitative, so the MDG's targets can be achieved in Aceh.

This is reinforced by the results of research conducted by Pusat Kajian Pendidikan dan Pelatihan Aparatur IV Lembaga Administrasi Negara (PKP2A IV LAN) Aceh, which reinforces the fact that the focus of the implementation of the Jaminan Kesehatan Aceh is the treatment (curative) as defined in point 6 associated with barriers and constraints in the implementation of JKA.

Based on the background, it can be formulated issues to be discussed in this article.

\footnotetext{
Pusat Kajian Pendidikan dan Pelatihan Aparatur IV Lembaga Administrasi Negara (PKP2A IV LAN) Aceh, Kajian Efektifitas Pelaksanaan Jaminan Kesehatan Aceh (JKA), page. 91
} 
The first is the model policies adopted by the government of Aceh and the district/city to achieve the MDGs; and secondly whether the achievement of the MDG's target in 2015 already achieve results as its indicators.

\section{METHOD}

The type of research used is an empirical research. This legal research is done by using the statute approach, as an approach which makes a legislation and regulation or norms/rules specific law as a basis to examine and analyze the reality of what happened. Furthermore, various norms or rules of law which will serve as the basis for testing whether reality that happened in the field have been appropriate or not with the rules as outlined in the norms/rules of the law.

The research was conducted in 3 (three) districts in Aceh province, i.e the districts of Aceh Besar, Pidie and Abdya. The choice of this location is based on considerations of representation between the Western and Southern region of Aceh (Aceh Barat Daya) with the Eastern-Northern region (Aceh Besar and Pidie). Besides, representation of 2 (two) districts that had long to implement regional autonomy, that is Aceh Besar and Pidie and a new district is enlarged that is Aceh Barat Daya.

As for the populations in this study are the various parties involved in the governance of Aceh and Pidie district administration, Aceh Besar and Aceh Barat Daya district whose duties and functions in the field of health.

The data obtained from the field will be processed and analyzed using qualita- tive approach, an approach that produces descriptive data analysis. The qualitative approach includes 4 (four) steps: data collection, data reduction, data presenting, and then draw conclusions/verification. Analysis of these data will be done systematically. The data obtained and are already assured of its validity will be shown descriptively and systematically, and then reduced until it can be concluded/verified.

\section{ANALYSIS AND DISCUSSION \\ Model Policy Adopted by Aceh Govern- ment to Achieve MDG's Target}

The visions of Aceh Government in 20122017 are dignified, prosperous, just, and independen based on UUPA as a realization of Memorandum of Understanding. A word that is incorporated in the sentence of Aceh government vision in 2012-2017 is prosperous the creation of public welfare through economic development are basically on the excellent potential of local and competitiveness, the optimizing of use of natural resources and Aceh geopolitical, improved human development index and develop the ability to master the advance of science and technology.

1. In order to realize the vision of Aceh is pursued through 5 (five) mission of Aceh development, one of which is what is formulated in the third mission, that is; strengthening the structure of the economy and the quality of human resources is to develop a framework of democratic economy through increased potency of the leading sectors of region in effort to build an optimal quality of life; 
2. Reduce poverty and unemployment in meeting the achievement of the Millennium Development Goals (MDG's), expanding employment opportunities through infrastructure development, real economy and siding with SMEs and cooperatives.

3. Economic development is focused on the agricultural sector which is based on local potentials of each region.

4. Improving the quality of education and public health services in Aceh is to realize the quality of education through increased the school participation rates, reduce the illiteracy rate, increasing the Gross Enrolment Ratio (GER) and Net Enrollment Ratio (NER) in various levels of education, reduce participation disparities between regions, gender and socio-economic as well as an educational unit.

5. Realizing the quality health services through increasing life expectancy, the decline in infant mortality, decreasing the prevalence of malnutrition as well as the effectiveness of the treatment of infectious diseases in order to achieve the MDGs.

The Aceh Government through the Department of Health through various policies in the health sector, one of the most popular is the social security policy in the field of health, known as Jaminan Kesehatan Aceh (JKA), which has now changed its name to Jaminan Kesehatan Rakyat Aceh (JKRA) in the era of Zikir administration.

There are several policies adopted by the Health Office in Aceh to achieve the MDG's target by 2015, namely:

\section{Monitoring and Track Record of Case}

Policies adopted by Aceh government in order to improve the health status of Acehnese people, especially in the achievement of MDG's is what is done by the health office in Aceh, one of them is the monitoring and Track Record of Case. This policy is very important in order to evaluate the existing policies and the achievement of future targets. This is evident from flashbacks and health learning of Aceh in 2012-2015, in which case there is a SMS point and track record. ${ }^{2}$

The government of Aceh through the health office in Aceh has made a road map towards the Millennium development targets starting from Baseline Data Performance 2010 - 2011 leading to the MDG's target by 2015 . One of the policies is in point 5 , a track record and tv monitor. ${ }^{3}$

Monitoring the case starts from midwife in the village up to the provincial level. If the case of infant mortality, maternal deaths, malnutrition and elected infectious diseases (including malaria, TB BTA new positive and HIV-AIDS) is found in the field, confirmation and tracking cases is done by filling the track record. In the track record is known grassroots causes of these cases, so that its expectation the intervention can be done correctly.

As an example of the format of a track record of maternal deaths (Form KI) are variables following the date of death, date of report, who report, received, mother identity, pregnancy history $(\mathrm{K} 1, \mathrm{~K} 4$, Immunization

\footnotetext{
Material of Review Roadmap MDG's Pembangunan Kesehatan di Aceh 2012-2015, Dinkes Aceh, 2015 page. 1

Ibid, page. 2
} 
TT Fe3, nutritional status, co-morbidities), history of labor (IMD/exclusive breastfeeding, pantograph, complications, normal, action), a history of puerperal (KF1, KF2, KF3, complications, co-morbidities, history of death, in response to the case at the level of districts (Health Officer and Hospital), Service Inequality Resume and also variable cause of death, learning and follow-up health centers, district/city and health office in Aceh.

\section{TV Monitor, Routine SMS and Case SMS}

One of the policies pursued by the government of Aceh in particular Health Office Aceh is to launch a TV Monitor program, Routine SMS and Case SMS. Policies pursued in order to speed up the flow of data and information using internet technology. With the rapid flow of data and its accuracy will allow policy makers to take strategic steps and appropriate to address any health problems experienced by the community, especially to achieve the MDG's targets. This policy has been adopted nationwide, as evidenced by the health office in Aceh invited to present this policy in the Ministry of Health of the Republic of Indonesia. ${ }^{4}$

The monitoring of case that has been done as mentioned in point 1 , periodically reported tiered by a midwife in the village to the head of health center, and to the head of district/city department and to the head of the health office in Aceh through Penjab of district/city that are already in health office in Aceh since 2013 ago. Practically, the report is sent via SMS, i.e monthly SMS, from the head of Health Department of district/city

4 Evi Syafrida, Kabid Pembinaan Pelayanan Kesehatan Dinkes Aceh, Interview 10 August 2015. and Director of the Hospital and case SMS is sent if there is a case. At the level of Health Office Aceh, the report is displayed via TV monitor of Health Office Aceh which is updated.

\section{Model of Special Program Policy}

In order to achieve the MDGs in the health sector, the Governor of Aceh ordered the Head of Health Department Aceh to create a special program in order to reduce infant mortality after birth. This policy is needed because the data shows an increasing trend, the data in 2013 recorded 808 infants who died, and in 2014 the number rose to 831 or an increase of $3.4 \%$. Besides, special programs are also needed to reduce malnutrition in Aceh but especially in districts/cities that its figure is still very high, Aceh Besar 57 cases, Pidie 47 cases and Aceh Timur 28 cases. To overcome this, it is necessary to cross-sector cooperation, and should be done comprehensively. Cooperation with the Office of Food Security and Education, Community Empowerment Board and other related agencies.

Cases of malnutrition are prevalent in the village, this is due to; first, because lack of knowledge some communities on the benefits of nutrition for pregnant women and infants, and second, is the issue of economic and earnings. One of the special programs is the importance of nutrition education programs for the health of pregnant women, and supplementary feeding for pregnant women and infants. The main role in the district/city, and this can be done by funds of special autonomous. 


\section{Model of Budget Balancing}

If look at the direction of national health development, it is seen that the RPJMN I (2005-2009), health development is directed to improve access and quality of health services, by strengthening curative and rehabilitative efforts. RPJMN II (2010-2014) is directed to the public access to quality health services have been more developed and increased with curative and rehabilitative efforts that lead to promotive and preventive efforts. RPJMN III (2015-2019) is directed to the public access to quality health services has started steadily with a focus on promotive and preventive efforts. While RPJMN IV (2020-2025) is directed to the public health to health services, quality has reached and evenly throughout Indonesia with a focus on promotive and preventive efforts in order to achieve the vision of a healthy community that is independent and fair. Thus it appears that the efforts towards the development of health, of curative moving towards promotion, prevention according to the conditions and needs. ${ }^{5}$

From the direction of health development as mentioned above, obviously Aceh must also follow the pattern of that policy, so there is a synergy in order to realize the highest health of the Acehnese people. This of course is linked to budgeting. For each program would require adequate budgeting. In connection with the achievement of the MDG's, alignments APBA budget in improving the nutrition of pregnant women and children under five are still little. When viewed in the total budget ceiling APBA in-

\footnotetext{
Akmal Taher, Bahan Presentasi Direktur Jenderal Bina Upaya Kesehatan, Kemenkes RI, pada Rakerkesda Provinsi Aceh, 13 April 2015.
}

deed, that is 1 trillion. But once seen alignments health improvement efforts is still very low and not comparable with curative. Whereas in a health is known an adagium "that prevention is better than cure".

However, as the budget sector policies, ignoring the adagium meant. The proof, budget for JKRA reach Rp. 464 billion. As for health improvement is only Rp. 3.4 billion. When compared with the support of the state budget for health improvement, then reached Rp.10,2 billion. It is time for the government of Aceh both legislature and executive need to do a balancing measures in question, so that the target achievement of the MDG's in Aceh can be realized.

\section{Model Policy Adopted by Regency/ Municipal Government in Aceh to Achieve MDG's Target}

\section{Make Supporter Program}

In order to improve health services to the community, especially in the districts/cities in Aceh, the government of Aceh has taken various policies either in relation to the services and support facilities. District/city government has a strong commitment to realize the vision and mission of the Regent/ Mayor in the health sector.

In connection with the target of achieving MGDs, the district government through the Department of Health has taken various efforts through programs in health, especially with regard to efforts to suppress the maternal mortality rate, infant mortality as did by the Department of Health Abdya with 28 program to support the achievement of the MDGs. In order to reduce infant mortality, it is necessary to visit the pregnant 
women in various villages. To facilitate monitoring, then in every health center appointed Bidang Koordinator (Bikor), to coordinate all midwives is underneath so the implementation of tasks can be run well, and facilitate communication with the Department of Health.

A programs carried out by the Department of Health Aceh Besar is conduct monitoring of infant mortality in the form of a table that contains the name, age, sex, child, address, date and place of death, the history of death, the officer in charge and a description. From the date of 16 January 2015 until 26 August 2015 there were 65 reports of infant deaths in Aceh Besar. ${ }^{6}$

To support the MDGs, especially suppress the maternal mortality, infant mortality; it is necessary to work hard in updating the data needed to determine the corrective measures. But even though midwives are trained in the use of IT, but in reality there are many midwives who are not able to operating these tools. As a result, the flow of data to be delayed from health centers to district and onwards to the province as well as to the Ministry of Health in Jakarta. This is because the need to transmit data manually. ${ }^{7}$

To achieve the MDGs target, which is very important is the training of health workers to search for cases through socialization targeting the cadres, the socialization of reproductive health for school children. This of course requires a cross-sector support. Strengthening health professionals through the latest upgrade science, especially for

Material of Monitoring Report of Infant Mortality of Aceh Besar, 2015, p 12

Satrinawati, Kasi KIA Dinkes Aceh Besar, Interview, 31 August 2015 senior midwife. Besides, it is quickly diagnosed cases in the field of nutrition. Need to prioritize services for pregnant women by providing special classes for pregnant women at health centers.

\section{All Village Midwife Must Stay in “Gampong”}

In addition, there is also a policy in the form of programs that seek to help childbirth conducted by professional midwives in order to reduce maternal mortality. Because of all this the fact there are still childbirth assistance given by midwives Gampong (mablien) although the numbers are not so much. Until now the number of delivery through professional midwife has reached $81.08 \%$ (Abdya). The same was found in Lamteuba Aceh Besar, there is still a trained shaman, which is equipped infection prevention science.

The number of midwives is still experiencing a shortage, because not every village has one midwife, as in Abdya which has 152 villages, but only had a total of 140 midwives, there is still a shortage of about 12 people midwife again. But it did not become an obstacle because it can be overcome by midwives alongside other village. All midwives live in the village, because it has become a policy since conducted recruitment midwives. They should not stay anywhere else, to facilitate the service, because the principle is how the service closer to the community.

Policy to present midwives in every village is to reduce the number of maternal deaths. If found cases of maternal death, it must be immediately reported to Bikor, with 
a clear explanation about the maternal mortality data, as an evaluation in the implementation of the program. The department of Health in district level shall immediately report to the provincial health office to determine strategic steps to press the case.

Midwives ratio to population, especially in Aceh Besar is met. The problem is the uneven distribution. It is caused by many factors, such as they are unwilling to live in remote areas like the island of Aceh. One of the policies adopted by the government of Aceh Besar is set midwife recruitment problems and transferring. The main problem is in transferring, because all the midwives wanted to live in a village near their home, would not be placed in far areas.

There are several factors that cause maternal deaths still occur despite the numerous programs to minimize them have been conducted by the district/city, this was mainly due to public awareness about the importance of health is still low, the level of education that the average is still at the level of Junior High School or equivalent as well as family support the importance of maintaining health, especially for pregnant women, is an important factor in reducing maternal mortality. Besides, there are several causes of high maternal mortality, namely bleeding, infection, delayed delivering, husband late in taking a decision, resulting in the death of the mother. There was also caused by faulty medical treatment. ${ }^{8}$

There are several models of policies adopted by the district/city governments in the health sector in the achievement of the MDGs, namely:

Satrinawati, Kasie KIA Dinkes Aceh Besar, Interview, 31 August 2015

\section{Adjustment to the ability of APBK}

Achievements of MDG's targets for the health sectors through various programs are implemented in accordance with the indicators are built. The target was included in the implementation and achievement of the minimum service standard in the district. It can be explored from the type of basic health services. In this service, there are 14 indicators.

If associated with budgeting, so not all indicators that its activity receive a budget allocation of APBK. Of the 14 indicators of basic health services in the districts of Pidie, only indicator of pregnant women visit K4 are obtained budget from APBK 2014, namely:

a. Program medicines and medical supplies Rp. 2.513.546.624;

b. Provision of additional food and vitamin Rp. 250.408.284;

c. Evaluation and development of health service standards Rp. 182.829.750; and

d. Improvement of public health services Rp. 528.067.500;

As the concrete steps undertaken by the District department is conduct monitoring of maternal mortality, maternal and infant deaths, make a list of investigations of infant deaths, create a form 1 (ANC), which consists of status TT pregnant women, risk detection and referral of cases highrisk, report achievement indicators of child health programs per year, making a recap of malnutrition, a recapitulation of Annual Report on Maternal and Child Health Services and to make Table Recapitulation of Application Development and Achievement 
of Minimum Service Standards per year.

All activities performed by the department of Health district as an effort to support the achievement of MDGs in the sector of health. Although it has made various efforts, but the success or failure of the program is not only determined by the government alone, but are influenced by other factors, such as budget support from the legislature, community participation to support government programs in health. One example is the case of malnutrition, without adequate family support, it is very difficult to overcome. In addition, other factors are no less important is the economic factor. The financial capability of the family is the determinant of nutrition. It is impossible to meet four healthy and five perfectly, if people are still living below the poverty line.

Relating to budgeting, there is an imbalance of the budget is plotted for curative, preventive and promotive. Though promotive is very important to reduce the number of maternal mortality, infant mortality, and also prevent malnutrition. Whereas, preventive is more difficult than curative. Budgeting for training activities, as if a waste of money, this is very effective for the improvement of public health. If things that are curative very rapid response in terms of budgeting, but it is not so urgent, like an increase in the health center status from inpatient to outpatient care.

In fact once made were not much visited by patients who need hospitalization, because they are closer to hospitalization to Banda Aceh. The improved status as if there is pressure from society as their aspirations, without understanding what happens after that status enhanced. ${ }^{9}$

Inequality between curative and preventive budget is also occurred in Pidie district, the budget of curative is $70 \%$ at the health center, $100 \%$ at the hospital. While the budget for preventive, are only around 5\% $10 \%$ of the total budget ceiling for the health sector. The inequality is large, APBK not able to maintain the budget balance between curative and preventive. ${ }^{10}$ DPRK is very concerned to support the program budget is needed in order to support the MDGs, no matter how needed by the Department of Health, will still be accommodated by the DPRK. The important thing is clear planning through TAPD, it will still be approved by the DPRK, it is very possible for a harmonious relationship between the executive and the legislative. ${ }^{11}$

\section{Regulatory Support}

In order to provide a strong legal basis for carrying out various activities included in the achievement of the MDGs in the health sector, it is in need of regulation, either in the form of local regulation/Qanun which received legislative support, as well as those made by the executive itself in the form of the Regent or Mayor regulations.

The results of research conducted in the districts of Pidie, Abdya and Aceh Besar are conditions almost the same, there is no regulation specifically intended to support the MDGs. This condition looks like in Pidie district, according to the letter sent by the Head of Health Department of Pidie

\footnotetext{
Wahyu, Kadinkes Aceh Besar, Interview 31 August 2015.

10 Reza Faisal, Kadinkes Pidie, Interview 7 July 2015

11 Sulaiman, Ketua DPRK Aceh Besar, Interview, $31 \mathrm{Au}-$ gust 2015
} 
District to the Regent of Pidie through the legal section, 20 April 2015, it appears that there are only two proposals Qanun in the executive, namely the draft of Qanun; No Smoking area and Regional Health System. But both new Qanun only a proposal, because until now there has been no research data collected draft. ${ }^{12}$

The condition described above proves that there is still very little support in the form of regulations to support and provide a strong legal foundation in order to carry out various activities in the health sector for the achievement of the MDGs. From the research, recently discovered a regulation related to health, namely, the Regent Regulation on Guidelines for Malaria Elimination well in Pidie or Abdya. The birth of this regulation to support the achievement of MDG targets, especially in relation to pregnant women and children less than five years old (toddlers), because it is the group most at risk if contracting malaria.

Ideally, all of the activities and programs in order to achieve the MDGs in accordance with the indicator must receive regulatory support, either in the form of Qanun and Regent/Mayor regulations, so as to have a strong legal foundation for their implementation, including support for a balanced budget and adequate in APBK to be fund various programs and activities in question.

Regulations related to malaria elimination, already exist, but are less effective. There is an impression as if the regulation made it only binds the Health Department only. In fact, these regulations must also be

12 Ramli, Kabag Hukum Pemkab Pidie, Interview, 7 July 2015 adhered to by the entire community in order to increase the degree of health. ${ }^{13}$

\section{The Achievement of MDG's Target in 2015 with its indicator}

To measure whether the targets that have been defined in achieving the MDGs been achieved or not, then it must be seen first on the indicators of achievement. In order to achieve these targets, the government of Aceh has been a movement called "Gerakan Sukses Menuju Target Pembangunan Millennium Bidang Kesehatan Tahun 2015”.

The MDG's first indicator is lowering the prevalence of malnutrition. Conditions now are malnourished children (23.72\%), while the condition of his/her hopes is smaller than $10 \%$, even if it could be zero. To achieve this is done through the steps nutritional surveillance activities with the movement of "Bangkit Posyandu". In addition, there is an indicator for the handling of cases of malnutrition (115.414 children under five), while the condition of case management expectations $100 \%$, all children are monitored growth. To achieve this is done through optimization of operational measures with "Gerakan Bangkit Posyandu" (Gerbank Posyandu)."

Other indicators of MDGs are monitoring growth/nutritional status of children. Conditions now are children malnutrition (3.2\% or 3.462$)$, while the condition of his/ her hopes $\mathrm{D} / \mathrm{S}$ is $100 \%$. To achieve this is done through operational measures; ensure the integrated service post and nutritional logistics with a movement Sadar Gizi Daerah,

\footnotetext{
13 Junaidi, Kabid P2pL Dinkes Aceh Besar, Interview 31 August 2015
} 
community empowerment as well as providing operational funding.

MDG's second indicator is reducing maternal deaths. The condition is now the number of maternal deaths (156 cases), maternal mortality ratio of 151/100.000 LH while the condition of his/her hopes $118 / 100,000 \mathrm{LH}$. To achieve this is done through Jampersal with quality standards with the movement of "Sayang Ibu".

MDG's third indicator is the decrease of child mortality. The condition is now the number of infant deaths (1546 cases), infant mortality ratio 15/1000 LH while his/ her hope $12 / 1000$. To achieve this is done through operational measures home visit with the movement of "continuum of care". A movement of interest groups for maternal and child health.

MDG's fourth indicator is to reduce the prevalence of communicable diseases. Current conditions of CDR (TB 56\%), while the condition of his/her hopes CDR (TB $80 \%$ ). The prevalence of TB and the current cure rate of API 0.61/1000 population, while the condition of hope $1 / 1000$ population. To achieve this is done through active case finding activities, monitoring, taking medication with the movement of "eliminasi malaria".

Movement "Clean Friday". Prevention of transmission of HIV/AIDS is now the number of cases is 21 , while the condition of his/her hopes is zero. Its activities ensure logistics and drug remain on health facility. Movement "Forum Peduli ODHA". Access to clean water and sanitation, access to clean water conditions now 56.37\%, 41.20\% access to sanitation, while the condition of his/her is greater than $70 \%$. Its activities in the form of business partners across the water sector, implement sectoral cooperation with the movement as "Penghijauan" as well as regulations for environmentally friendly development.

Data obtained from the TV monitor of health office in Aceh edition in April 2015 on form $\mathrm{E}$ about pursue MDGs, it appears that the increase in life expectancy target of 72 years, Aceh is still 69 years old, fall in infant mortality rate (IMR per 1,000 born alive was 24 ) in 2014 still 12, and 2015, this condition is 12 . The decline in the maternal mortality ratio is also still does not meet the target of 102 per 100.000 live birth, achievement of Aceh in 2014 was 123, and April 2015 is 102.

The decline in the prevalence of malnutrition, nationally 15\% while Aceh 12 $\%$ in 2014. Recapitulation of case SMS (KI, $\mathrm{AKB}, \mathrm{LM}$, Malnutrition data is available by name and address in the health office in Aceh. Recap of SMS until April 2015, stillbirth 106.22 , maternal mortality 22 , infant mortality 185 and Gibur 29 cases. The fall in the prevalence of HIV and AIDS, national $<0.5 \%$, Aceh in 2014 already reached the $0.5 \%$. The fall in malaria morbidity, national target of $<1$ per mil, Aceh achievements in 20141 per mile. Increased discovery of TB BTA new positive nationally $>70 \%$, while Aceh in 2014 was $70 \%$.

The seven of indicators of MDGs achievement is only 3 indicators have reached the target of the decline in the prevalence of HIV and AIDS, nationally < $0.5 \%$, Aceh in 2014 already reached $0.5 \%$. The fall in malaria morbidity, national target 
of $<1$ per mile, Aceh in 2014 is 1 per mile. Increased discovery of TB BTA new positive nationally.

To achieve maximum results, takes time and energy as well as the seriousness of various parties, especially the policy makers and the courage to make a breakthrough and innovation so that the results are maximized. This is in accordance with the opinion of Asnawi ${ }^{14}$ mentioning that to realize the achievement of the MDGs requires a specific policy, in the form of specific policies, not only do something mediocre or carry out routine daily tasks. If you need to conduct a comparative study into areas that have successfully made the breakthrough in the achievement of targets as there are areas that have been able to suppress the maternal mortality rate, infant mortality, and reduce malnutrition.

Moreover, a strange thing and a dilemma, when Aceh was a lot of money, it is precisely the achievement of MDGs is not maximized. In particular, the issue of nutrition. This is proven by the presence of the Acehnese people who are less good physical development (stunting).

According to Asnawi, allocation of Aceh health budget is less effective, due to a higher priority on curative measures so that the portion of the budget is greater in APBA for JKRA program. Though health measures that must be done comprehensively, integrated and sustainable with a focus on activities not only on things that are curative, but also need enough attention to promotive and preventive efforts. The amount of budget for JKRA, it only benefits perceived 14 Asnawi, Ph.D, Dean of FKM Unmuha Aceh, Interview 2 November 2015 by health workers obtain adequate medical services. For the people, for the short term is beneficial because it can be treated for free, but need to think about long-term benefit for improving the health of the Acehnese people. Such as how to help pregnant mothers so that their fetuses have adequate nutrition, so that will give birth to a healthy generation and can build the future of Aceh better. When viewed from the formulation of the achievement of MDGs in RPJM 20122017 , it did not translate well in budgeting, so it looks imbalance between promotive and preventive with curative and rehabilitative efforts.

Life expectancy is now only 69.20 for Acehnese peoples, this is caused by a lack of effort as well as a breakthrough policy dealing with the fall in infant mortality, maternal mortality as well as a decrease in malnutrition rates. Target of Acehnese life expectancy is only 69.20, lower than the target of national life expectancy, which is 72.0 years. To align with the national life expectancy, then there is no other way, except for the hard work and the support of various stakeholders, especially adequate attention to the improvement of nutrition, especially nutrition of pregnant women.

According to Abdul Fatah that malaria elimination program as a policy, it can only be done for the 15 districts/cities in Aceh. Its target, all districts/cities have to do malaria elimination program. So the Acehnese community health improvement can be realized. ${ }^{15}$ The program is very good, but its implementation is still not able to cover all the districts/cities in Aceh. This policy 15 Abdul Fatah, Kabid P2PL Dinkes Aceh, Interview 11 August 2015 
is supported in the form of Regent/Mayor regulation. To accelerate, this necessarily requires a strong boost as well as an adequate budget, primarily to support programs that are preventive.

\section{CONCLUSION}

The achievement of MDG's target in the health sector is not maximized as expected, because not all indicators can be achieved. It is highly dependent on budgetary support from both APBK and APBA. Model policies adopted by the Aceh government is monitoring and track record of cases, TV monitor, routine SMS and case SMS, a special program policy models, models of balancing the budget. Model policies adopted by the district/city government is making a supporting program, all village midwives Must Live in the Village, assistance deliveries performed by professional health workers, adjustment to the ability of APBK. Support new regulation of Regent regulation on Malaria Elimination and No Smoking Area.

The executives should be advocating sustained to the legislature for an increase in the budget allocation in both APBA and APBK in achieving the MDG's targets in the health sector. The legislative and executive governments in Aceh need to perform concrete steps to balance the budget support for health promotion programs, prevention, curative rehabilitative.

\section{BIBLIOGRAPHY}

Husni Jalil. (2005). Eksistensi Otonomi Khsusus Provinsi Nanggroe Aceh Darussalam dalam Negara Kesatuan
Republik Indonesia Berdasarkan UUD 1945. Bandung: CV. Utomo. Husni Jalil. (2010). "Implementasi Otonomi Khusus di Provinsi Aceh Berdasarkan Undang-Undang Nomor 11 Tahun 2006”, Jurnal Ilmu Hukum Kanun, Vol. 51 Tahun XII, Edisi Agustus.

Inu Kencana Syafei. (1999). Ilmu Administrasi Publik. Jakarta: Rineka Cipta.

Lembaga Administrasi Negara, (2010). Manajemen Pelayanan Inklusif. Jakarta: Lembaga Administrasi Negara.

Lembaga Administrasi Negara. (2006). Strategi Peningkatan Kualitas Pelayanan Publik. Jakarta: Lembaga Administrasi Negara.

Peter Becker. (2009). Penguatan Kerangka Kerja Hukum Dalam Mengatur Bidang Kesehatan di Aceh. AGSI.

Peter Mahmud Marzuki. (2007). Penelitian

Hukum. Jakarta: Kencana Prenada Media Group.

Philipus M. Hadjon. (2002). Pengantar Hukum Administrasi Indonesia. Yogyakarta: Gadjah Mada University Press.

Aceh Qanun No. 4 of 2010 concerning Health.

Aceh Qanun No. 8 of 2008 concerning Public Services. 